Waal, B.M.E. de, Batenburg, R., Fruytier, B. Metastructuration actions of management: critical for stakeholder intervention in IS/IT implementations. International Journal of Healthcare

\begin{tabular}{|l|l|}
$\begin{array}{l}\text { Postprint } \\
\text { Version }\end{array}$ & 1.0 \\
\hline Journal website & http://www.inderscience.com/info/inarticle.php?artid=50635 \\
\hline Pubmed link & \\
\hline DOI & $10.1504 /$ IJHTM.2012.050635
\end{tabular}

This is a NIVEL certified Post Print, more info at http://www.nivel.eu

\title{
Metastructuration actions of management: critical for stakeholder intervention in IS/IT implementations
}

Benny M.E. de Waal*:Research Centre for Innovation and Business, University of Applied Sciences Utrecht, Padualaan 101, 3584 CH Utrecht, The Netherlands E-mail: benny.dewaal@hu.nl *Corresponding author

Ronald Batenburg: Netherlands Institute for Health Services Research (NIVEL), P.O. Box 1568, 3500 BN Utrecht, The Netherlands and Institute of Information and Computing Sciences, Utrecht University, P.O. Box 80089, 3508 TB Utrecht, The Netherlands E-mail: r.batenburg@nivel.nl

Ben Fruytier: Research Centre for Social Innovation, University of Applied Sciences Utrecht, Heidelberglaan 7, 3584 CS Utrecht, The Netherlands E-mail: ben.fruytier@hu.nl

\begin{abstract}
:
Metastructuration actions (overarching activities from management that shape and align users' activities of IS/IT use) are often advocated to improve the success of IS/IT implementation. But how can management support enhance the success of IS/IT by metastructuration actions, when they are dealing with multiple stakeholders? This key question is addressed in this paper. Building on Orlikowski et al. (1995), we explore the contextual conditions of metastructuration actions of management concerning three other key stakeholders: users, the IT department, and external service providers or consultants. The empirical case context is a Dutch public healthcare organisation that deployed three (different) departmental information systems . Based on 26 interviews with all stakeholders that were involved in the deployment of the three departmental information systems, we find that three types of metastructuration actions were critical in a particular relationship with two types of stakeholders. We conclude that this demonstrates that stakeholder context is indeed conditional to metastructuration actions, and hence the success of an IS/IT implementation in terms of perceived system quality and acceptance
\end{abstract}

\section{Reference}

to this paper should be made as follows: de Waal, B.M.E., Batenburg, R. and Fruytier, B. (2012) 'Metastructuration actions of management: critical for 
Waal, B.M.E. de, Batenburg, R., Fruytier, B. Metastructuration actions of management: critical for stakeholder intervention in IS/IT implementations. International Journal of Healthcare Technology and Management: 2012, 13(4), 242-261

stakeholder intervention in IS/IT implementations', Int. J. Healthcare Technology and Management, Vol. 13, No. 4, pp.242-261 .

\section{Biographical notes:}

Benny M.E. de Waal is a Lecturer and Researcher of the Research Centre for Innovation and Business at the University of Applied Science Utrecht. He obtained his Bachelor of Applied Sciences at the University of Applied Science Breda and his Masters of Art at Tilburg University. Formerly, he was employed as a Researcher at Eindhoven University, the Netherlands. His focus is on information systems and quality of work, and on user participation in the process of development and implementation .

Ronald Batenburg is an Associate Professor in Information and Computing Sciences at Utrecht University. Since 2009, he is also a Programme Coordinator of healthcare and manpower planning at NIVEL, Netherlands Institute for Health Services Research. He received his PhD at Groningen University, the Netherlands, and was formerly employed as an Assistant Professor at Tilburg University and Nijmegen School of Management. Recently his focus is on how IT adoption and implementation can improve healthcare organisations and professions . Ben Fruytier is an Associate Professor at Radboud University Nijmegen and a Professor at Utrecht University of Applied Science. His research activities concentrate on the field of organisational design and change in professional organisations. His special areas are higher education and healthcare .

\section{INTRODUCTION}

The healthcare sector is a critical social and economic part of modern society, and the acceptance and effective use of health information systems/information technology (IS/IT), such as medical imaging technology, information systems, computer-aided diagnosis, decision-support systems and electronic patient record, is crucial to its success (Chiasson et al., 2007). The acceptance of IS/IT in healthcare organisations is influenced by several actors that have different backgrounds and experience. Therefore, it has been widely stated that healthcare actors should be carefully managed as their role is important during the process of acceptation (Strong et al., 2009; Mantzana et al., 2007). Allsop and Taket (2003) state that providers and other stakeholders of health services who assess their strategies in relation to user involvement achieve higher success in IS/IT implementations. Another example is a study on implementing IT in hospitals (Walley and Davies, 2002) shows that internal barriers significantly constrain the implementation process, such as an unsupportive organisation structure, irreconcilable differences in stakeholder requirements, the low status of the project team, a poor understanding of process management issues and organisation politics .

The issue of IS/IT success in (all types of) organisations has a long research tradition (cf. Allsop and Taket, 2003; Barki and Hartwick, 1989, 1994; DeLone and McLean, 1992, 2003; Hartwick and Barki, 1994; Hebert, 2000; Jeyaraj and Sabherwal, 2008; Kappelman and McLean, 1991; Lynch and Gregor, 2004; Markus and Keil, 1994; Orlikowski, 1992, 2000; Seddon et al., 1999; Venkatesh et al., 2003). IS/IT success can be divided in development success and implementation success (He and King, 2008; Markus and Mao, 2004). Development success is described as the functional outcomes of a IS/IT project (e.g., system quality, progress against schedules and budgets) . 
Waal, B.M.E. de, Batenburg, R., Fruytier, B. Metastructuration actions of management: critical for stakeholder intervention in IS/IT implementations. International Journal of Healthcare Technology and Management: 2012, 13(4), 242-261

Implementation success is described as the desired outcomes from the perspective of the users (e.g., system use, acceptance, user satisfaction) .

A number of studies demonstrate that management support is an important determinant of IS/IT success (Akkermans and Van Helden, 2002; Lewis et al., 2003; Nasirin et al., 2005; Nordheim and Nielsen, 2008; Purvis et al., 2001; Sharma and Yetton, 2003; Somers and Nelsen, 2001). Lewis et al. (2003) argue that beliefs about the use of information technologies stem from three sets of influences: individual, institutional and social. They assessed these beliefs in terms of their usefulness and ease of use in the context of a contemporary technology targeted at autonomous knowledge workers. Their conclusion was that beliefs about technology use are strongly influenced by management commitment to the new technology as well as the individual factors of personal innovativeness and self-efficacy. In a study on DSS project implementation, Nasirin et al .

(2005) studied four factors influencing user involvement. Of these four factors, senior executive awareness and support were equally important as user's perceived task complexity, user's resistance to change and user training. Nordheim and Nielsen (2008) investigated the role of a corporate user representative from the perspective of three organisational influence processes: downward, lateral and upward. It was found that a corporate user representative in a high formal position and with lateral and downward influence processes to a steering committee and a project group was very influential .

They therefore state that a corporate user representative should be a management function, with adequate formal position to avoid upward influence processes. In a meta study, Sharma and Yetton (2003) found that high management support is a necessary and critical component of a successful implementation strategy when task interdependency is high, but a relatively weak and less critical component when task interdependence is low .

Their research was based on 22 empirical studies in journals, books and unpublished theses and dissertations .

Given these many types of illustration and evidence, in practice, management support in relation to IS/IT success can mean many things. The particular actions behind management support that influence IS/IT implementation success is actually less investigated. One idea was suggested by Purvis et al. (2001), which found evidence that management's championship of a technological innovation is most effective when focused on so-called 'metastructuration actions' - a concept first introduced by Orlikowski et al. (1995). These actions are described as "activities that shape other users' activities of use” (p.425). New questions arise from this, however, if during the development and implementation of IS/IT, multiple stakeholders are involved to realise a specific (partial) artefact. This is particularly to be excepted in large and complex organisations, such as the healthcare sector where strong professional roles, explicit hierarchies, specialised expertise, and many laws and regulations are present (Axelsson et al., 2011). So if we want to elaborate the perspective that management is not the only actor at stake in metastructuration actions, and apply it to the context of healthcare organisations implementing new IS/IT, a relevant research question is: how can management support enhance the success of IS/IT by metastructuration actions, when management is dealing with multiple stakeholders? 
Waal, B.M.E. de, Batenburg, R., Fruytier, B. Metastructuration actions of management: critical for stakeholder intervention in IS/IT implementations. International Journal of Healthcare Technology and Management: 2012, 13(4), 242-261

We realise this is a major research question that is hard to answer by one study in a definitive way. Therefore, in this paper, we take this question as a starting point to present and interpret insights and empirical cases from Dutch healthcare organisations that replaced and implemented their critical IS/IT applications. We present a comparative analysis of three IS/IT projects by using the case study methodology. In doing so, we describe the insights we gained by investigating the development and implementation of three departmental IS/IT systems, using a (combined) metastructuration and multiple stakeholder perspective .

The paper is structured as follows. In the next section, the concept of metastructuration actions is described including stakeholder interactions. Thereafter, the threefold case study setting is described. In Section 4, the collected and analysed qualitative data are described and explained. The paper concludes with a discussion of the findings and suggestions for further research .

\section{A METASTRUCTURATION AND STAKEHOLDER PERSPECTIVE}

According to Orlikowski et al. (1995), two sets of actions characterise the dynamics of technology deployment in organisations: individual structuring actions and metastructuring actions. The first set consists of actions taken by users to appropriate technology features and to adapt technology to accomplish work. The second set includes direct actions to make the technology more valuable to users and indirect actions to manipulate prevailing institutional structures, such as workflow patterns, work procedures, routines, reward systems and control and coordination mechanisms. Research shows that metastructuring actions are undertaken by and under the responsibility of management and so-called 'technology champions' (Akkermans and Van Helden, 2002; Dong et al., 2009; Jensen et al., 2009; Mignaret and Rivard, 2009; Purvis et al., 2001; Sharma and Yetton, 2003). From these studies it is widely expected that management support has a direct influence on IS/IT success

The effect of management support on IS/IT success was investigated by (among others) Sharma and Yetton (2003). Their study departs from the proposition that the institutional context affects end users' ability and motivation to successfully adopt and use IS/IT innovations and applications. Further, the institutional context can be shaped in a manner that facilitates successful implementation, such as material and managerial resources and the symbolic actions or support of senior managers. One can think of a 'visible association' with the project, active championship, organisational communications or personal use of technologies. Also, managers need to mandate, negotiate, persuade, motivate and support end users in adopting IS innovations .

Management support is also needed for changing work processes and existing routines .

The (basic) conceptual model that be derived from these studies is depicted in Figure 1 .

As argued earlier, metastructuration actions cannot be considered as general, unconditional success factors for IS/IT success as they typically interplay with different stakeholders (Boonstra et al., 2008; Fehse and Krabbendam, 2004; Griffith and Sobol, 2000; Ko et al., 2005; Lin and Silva, 2005; Mantzana et al., 2007; Walley and Davies, 2002). According to the stakeholder theory, every legitimate person or group participating in the activities of a firm do so to obtain benefits. The priority of 
Waal, B.M.E. de, Batenburg, R., Fruytier, B. Metastructuration actions of management: critical for stakeholder intervention in IS/IT implementations. International Journal of Healthcare Technology and Management: 2012, 13(4), 242-261

the interests of all this legitimate stakeholders is not self-evident (Donaldson and Preston, 1995). Following Mitroff (1983), stakeholders can be defined as "all those parties who either affect or who are affected by an organization's actions, behaviours and policies” [see Boonstra et al., (2008), p.102]. Also, several scholars have pointed out that stakeholder relationships do not occur in a vacuum of dyadic ties, but rather in a network where stakeholders have direct relationships with one another (Rowley, 1997; Wolfe and Putler, 2002). Therefore, research must take into consideration the multiple inter-related stakeholders, concurrently (Chan and Pan, 2008) .

\section{[FIGURE 1] [FIGURE 2]}

For most IS/IT projects, four major stakeholders can be defined: management, users, IT departments and external parties (e.g., service providers and/or consultants). Hence, metastructuration actions, as defined above, should be specified according to the interactions between these four stakeholders. In addition, metastructuration actions should take the interaction between stakeholders into account, such that a 'level playing field' of IS/IT deployment within an organisation can be drawn. In Figure 2, the dotted lines illustrate this interplay between stakeholders and their relation to managements' metastructuration actions. All four actors interact with each other, while management takes a central position because this actor initiates the metastructuration actions. In principle, all metastructuration actions are applicable for each (set/type of) stakeholder interactions. It remains an explorative empirical question, however, which interaction between stakeholders makes a metastructuration action more or less effective, in terms of management support and thereby IS/IT success. Therefore, we consider the conceptual model, as shown in Figure 2, as a framework of all potential (and conditional) effects of metastructuration actions in relation to stakeholder interactions. The three IS/IT implementation case studies described in the next section inductively show which metastructuration actions actually matter to stakeholders and stakeholder interactions

The cases also inductively show the conditional effects of metastructuration actions on the successes of the three IS/IT implementations. After these analyses, the empirical value of the framework is evaluated .

\section{THREE IS/IT PROJECTS AT A DUTCH PUBLIC HEALTHCARE ORGANISATION}

The case study organisation that served as the host of the three IS/IT implementation projects to be analysed is a large public healthcare service in the Netherlands. It has about 1,250 employees and its primarily goal is to execute public health policies and regulations. The Board of the organisation is the General Director and the Medical Director. Because of the large diversity of work, the organisation is divided into nine so-called 'clusters', each with a fixed set of tasks. The field research took place within three largest clusters of the organisation, i.e., the social mental health (SMH), youth healthcare (YHC) and infectious diseases (ID) cluster .

The SMH cluster grants socio-medical care for people who, because of their mental states neglect and behaviour, are a problem or risk to public order. This includes problematic drug addicts, homeless persons and criminals, probably partly on the basis of medical problems. Because of the need for cooperation with various parties, a client tracking system was established. There was also an ever-increasing pressure 
Waal, B.M.E. de, Batenburg, R., Fruytier, B. Metastructuration actions of management: critical for stakeholder intervention in IS/IT implementations. International Journal of Healthcare Technology and Management: 2012, 13(4), 242-261

from society to move to digital imaging and to make use of the exchange of information to improve quality of care .

The time frame of the project at SMH is depicted in Figure 3. In 1999, a new IS was required to support work processes. The IT department at that time was centralised. On the basis of this research, a European procurement process was started. Altogether, 23 companies were interested in developing and deploying the system. Five companies were invited to submit a quotation (shortlisted). At the beginning of 2002, one of the companies was selected. In conjunction with another company, this service provider started to build the client tracking system. The other company was responsible for a system to register the use of methadone. The project leader was an employee from the service provider, who was accompanied by a project manager from the other company .

The responsibility of the project within the organisation was the head of SMH. In October 2003, the system went live. After the implementation of the system, the role of the service provider changed from system developer to system administrator. In this period, several changes to the system were made .

\section{[FIGURE 3]}

The YHC cluster provides youth healthcare to all children aged up to 19 years. The prevention and early detection of problems, as well as guidance about proper care, is its primary goal. To address these issues doctors or nurses often referred cases to the family doctor, youth care or other institutions. In addition to care, YHC has a proactive and/or participatory role in a variety of programmes and projects. YHC also provides services and products .

[figure 4] In Figure 4, the time frame of the YHC project is presented. At the beginning of 2003, it was decided to cooperate with another public healthcare organisation to digitise the client administration. In March 2004, after a European tender, a service provider was chosen to deliver the system. The members of the steering committee were the managers of YHC of both organisations, an external project manager, the head of the IT department and the project manager of the service provider. The service provider developed the system in cooperation with various working groups. The system was incrementally implemented in several consultation offices. Around 2006-2007, a new combination of service providers supported the system. In the past few years, several other public healthcare organisations in the Netherlands have started to use the system .

Third and final, the ID cluster deals with combating infectious diseases in society by means of screening at-risk groups, research and treatment. Part of the cluster is the regional laboratory, where biological material is investigated for the public healthcare organisation and several other institutions. Another part of the cluster, the department of global infectious diseases, provides travel advice and travel vaccinations. ID also has an instructive role in outbreaks or threats of contagious diseases .

Figure 5 shows the time frame of the ID project. Around 2001-2002, three sections within the department - the SOA policlinic, global infectious diseases and regional laboratory - were in need of a new IS. As a first step, an information analysis was carried out by an external consultant. On the basis of this analysis, a European tender was started to serve the SOA policlinic and global infectious diseases sections. The regional laboratory decided to start a separate project. After this tender, the regional 
Waal, B.M.E. de, Batenburg, R., Fruytier, B. Metastructuration actions of management: critical for stakeholder intervention in IS/IT implementations. International Journal of Healthcare Technology and Management: 2012, 13(4), 242-261

laboratory chose the same service provider as had the other two departments. In October 2003, a train-the-trainer programme was started. After the deployment, the service provider installed new requirements in the system .

\section{[FIGURE 5]}

\section{RESEARCH METHOD}

To analyse and interpret all the collected data a multiple case study design was applied .

The reasons for this was twofold. First, as the research question that drives our study is suggesting, we aim to answer a 'how' question, for which exploration is the key approach, and a case study is the most suitable method (Yin, 2009). Second, the effect of metastructuration actions on implementation success, to describe from a stakeholders multiple inter-related perspective, is very complex and contextual linked task. This also makes a qualitative (case study) approach justifiable (Klein and Myers, 1999). As we, at the same time, aim to discover patterns form systematic comparison and measurement of the case study material, we consider our data collection and analysis as "soft positivism" or "scientific realism" (Kirsch, 2004; Madill et al., 2000). In this approach data is analysed with certain expectations based on prior theories, while also unexpected findings and explanations from the data are generated .

For each of the three departmental cases, multiple data sources were used, including semi-structured interviews, and internal documents (e.g., project status reports, annual reports, project documents, project proposals, memo's, and contracts). The interviews were used to get detailed information about the implementation of the departmental IS and the interaction between the different stakeholders. The information gathered included different issues, such as the set-up and execution of the project, the actions to gain support, the task of each stakeholder, the attitudes and behaviour towards the new system, and the influence and experience of the different stakeholders .

In total, 26 interviews were conducted. Table 1 shows the distribution of the interviews for the three projects by stakeholder. Interviewees were partly selected by the head of the IT department and partly by the heads of the three clusters. In addition, the head of the IT department managed the contact with the external parties (service provider and external consultants). The outline of the interview guide is given in appendix A. The interviews were focused on getting answers to topics related to the actions management had undertaken to ensure the system was accepted and in which way these actions were influenced by other stakeholders' behaviour. Therefore, 'why' and 'so what' questions were asked to investigate the relationship between metastructuration actions and IS/IT success. Mostly, the outline was followed, but depending on the answers given by the participants, deviation occurred. The interviews took place in May and June 2009. The interviews were tape-recorded and a report was made from each (Patton, 2002). This report was sent to the interviewee for approval. Comments and corrections were incorporated into the interview report . 
Waal, B.M.E. de, Batenburg, R., Fruytier, B. Metastructuration actions of management: critical for stakeholder intervention in IS/IT implementations. International Journal of Healthcare

Technology and Management: 2012, 13(4), 242-261

\section{[TABLE 1]}

\subsection{Analysis procedure}

For each IS/IT project the interviews were analysed using a cumulative editing approach as summarised in Table 2 (Runeson and Höst, 2009). Each interview report within a certain stakeholder category was read carefully by the researchers in order to determine the meaningful fragments of text. These fragments were coded using open coding .

Fragments of text from within one interview and between interviews within the same stakeholder category were compared in order to determine whether or not they had the same code. If necessary, it was decided to merge codes or to change a fragment to another code following an axial coding procedure. This procedure was repeated for the other stakeholder categories. Thereafter, the fragments and codes of the four stakeholder categories were compared. In addition, when necessary, changes were made to codes, and fragments were replaced. The last step was to structure the codes at the level of main- and sub-variables/dimensions using selective coding. These steps were repeated for the other cases. Thereafter the three cases were compared which resulted in a structured identification of fragments relating to the different concepts that are presented in the next section (Miles and Huberman, 1994; Neuman, 2002; Boeije, 2002) .

\section{[TABLE 2]}

\subsection{Validity procedure}

In this case study research four aspects of validity are applicable: construct validity, internal validity, external validity, and reliability (Yin, 2009). Construct validity in this study is handled by using multiple sources of evidence and defining measurements by a protocol that was used to each case study. The internal validity was protected by conducting interviews with several actors in order to cross-check documentation, and to check statements made in different interviews. To govern external validity, multiple case studies were set up for comparison, in particular with regard to stakeholders and their influence on management support and IS/IT success. Finally, to ensure reliability, interview reports were send to the interviewees for approvals and case study reports was reviewed by the key informant. To generally govern validity, the case study protocol and a case study database was created and communicated with all subjects .

\section{RESUlTS}

For the metastructuration actions of management, three concepts can be identified (inductively) from the three cases studies. The first concept is 'awareness creation' . Multiple interviewees commented on the way the system was introduced and the activities undertaken by management. The second concept identified is 'training'. Many statements were about the way the system had been taught and the conditions under which this occurred. The last concept recognised as a metastructuration action was 'user participation'. This concept included comments on how employees were involved and participated in the different projects .

Stakeholder context revealed two concepts. The first one was 'alignment'. In this concept, comments about the cooperation, interaction and coordination between 
Waal, B.M.E. de, Batenburg, R., Fruytier, B. Metastructuration actions of management: critical for stakeholder intervention in IS/IT implementations. International Journal of Healthcare Technology and Management: 2012, 13(4), 242-261

different stakeholders appeared. The second concept was 'vision sharing'. Here, statements about the core objectives and ideals for the new systems were grouped . At least two concepts on IS/IT success were identified. The first concept was 'system quality'. With regard to this concept, multiple interviewees judged the usefulness, usability and operability of the system. The second concept was 'acceptance'. This concept was chosen to cluster statements about the use, adoption and (non)resistance of the system. Table 3 summarises the statements on the concepts for each stakeholder in the different projects. In the next sections, the main findings of each project on these concepts are described .

\subsection{The IS project in the SMH cluster}

- Management support. Table 3 implies that awareness creation in this project had not been sufficiently established. Different stakeholders indicated that there was not enough attention paid to using the system. Furthermore, the training was not articulated in an active way. On user participation, the views of the different stakeholders were different. Management and the IT department had opposite views . - Stakeholder context. The stakeholders indicated that interaction and alignment during the project between the stakeholders was insufficient. Mutual expectations were not managed well. In addition, there was no agreement about the goals of the system. All in all, the conditions for successful metastructuration actions were poor . - IS/IT success. On system quality, the stakeholders indicated that the quality did not fulfil the general expectations. The usefulness of the system was unclear and lacking

Furthermore, there were remarks about the usability of the system because it was too complex, and too many actions were required to enter and retrieve information. The acceptance of the system was low. From the beginning, there was limited use of the system, even avoidance by workarounds .

\subsection{The IS project in the YHC cluster}

- Management support. On awareness creation, the stakeholders revealed different statements. During the implementation, office assistants provided help, while the number of production targets was reduced. By contrast, the role of the regional manager seemed far from perfect. A reason for this was the reorganisation of the cluster during the project. Therefore, the commitment to the project was different for each regional manager, which also affected the training on using the system . Training was offered to all employees, but only used to a limited extent. User participation was formerly established. The selected group was, however, not a reflection of the end users. Participants were selected from only one office and by their computer skills .

- Stakeholder context. The alignment between different stakeholders varied. The service provider had direct contact with the user organisation, without the assistance of the IT department. At a later stage, when the system was inherited by a consortium of multiple service providers, the cooperation was adjourned. From the beginning of the project, there was no agreement about the goal of the system. The two public healthcare organisations in the different regions did not agree on the functionalities of the system. During the project, more and more objectives emerged . This resulted in 'much policy and little direction', which is a difficult condition for management metastructuration actions to have an optimal effect . 
Waal, B.M.E. de, Batenburg, R., Fruytier, B. Metastructuration actions of management: critical for stakeholder intervention in IS/IT implementations. International Journal of Healthcare Technology and Management: 2012, 13(4), 242-261

- IS/IT success. On system quality, different comments were made. It was noted that the system operates reasonably well, apart from the many 'click moments' that were experienced as negative. Furthermore, it was mentioned that at the beginning the workflow of the system was not in line with actual work processes. Acceptance was an issue as well. Many employees saw the system as a negative impact on their daily practices. Furthermore, many employees were not used to working with IS/IT. This was especially the case with older workers. All these factors caused a significant level of resistance .

\section{[TABLE 3]}

\subsection{The IS project in the ID cluster}

- Management support. As shown in Table 3, in the initial setup of the project, an information bulletin was used to inform employees about the development of the system. Furthermore, employees were trained to work and interact with the system . Between stakeholders, there was no agreement about the amount of training. User participation was received positively. In all phases of the project, employees were involved .

- Stakeholder context. The interaction between stakeholders was mainly considered good. There was, however, no general agreement about the goals of the system . Compared with the other cases, however, conditions were in favour of the potential effect of the management's metastructuration actions .

- IS/IT success. Stakeholders agreed about the system quality. Most requirements were satisfied. From the users' points of view, resistance to the system was reduced and everyone worked with the system, although not 'in depth' .

\subsection{Cross case analysis}

The researchers translated the findings into a three-point scale to compare the cases (see Table 4). To this end, the researchers scored the realisation (presence) of metastructuration actions of management, the favourable conditions of stakeholder context and IS/IT success, for the three cases, as (relatively) 'low', 'moderate' or 'high' .

\section{[TABLE 4]}

In all three projects, IS/IT success was different. In the SMH project, the IS/IT success was 'low', in the YHC project 'low/moderate' and in the ID project 'moderate/high'. The identified metastructuration actions by management in the three projects were low/moderate, moderate and moderate/high, respectively. If we focus on these three projects, the conclusion can be drawn that the realisation of metastructuration actions by management was related to better IS/IT success. Furthermore, the three case studies suggest that alignment and vision sharing, as stakeholder contexts, were more favourable in the ID project than they were in the other two projects. Thus, stakeholder context in the ID project was better which was accompanied by better IS/IT success and metastructuration actions. In the two other projects, the opposite occurred. Alignment and vision sharing were less in favour of metastructuration actions. Hence, metastructuration actions and IS/IT success was only weakly related. From this, it can be concluded that stakeholder context indeed influenced the realisation of metastructuration actions as well the success of IS/IT in terms of perceived system quality and the acceptance of the system . 
Waal, B.M.E. de, Batenburg, R., Fruytier, B. Metastructuration actions of management: critical for stakeholder intervention in IS/IT implementations. International Journal of Healthcare Technology and Management: 2012, 13(4), 242-261

\section{Discussion}

This paper aimed to answer the question of how management support can enhance the success of IS/IT by metastructuration actions, when management dealing with multiple stakeholders. Within a large Dutch public healthcare organisation, the development and implementation of three IS/IT projects were analysed. Data were collected by 26 interviews divided over three projects. The analysis of the interviews showed that three concepts were identified for management metastructuration actions, namely awareness creation, training, and user participation. It appears that these metastructuration actions are sensitive to the stakeholder context in terms of alignment and vision sharing. When this is not properly taken into account, metastructuration actions have less impact and system quality and user acceptance declines. This result actually brings the existing studies on metastructuration a step forward. Although these behaviours have been mentioned in previous studies (e.g., Purvis et al., 2001; Sharma and Yetton, 2003; Markus and Mao, 2004), they were not investigated in the context of stakeholders interaction. This study showed that stakeholder context is indeed a critical condition for the metastructuration actions of management to enhance IS/IT success. This result is actually resembling the work of Markus and Mao (2004) in practice, which is rarely done. In their IS participation theory, Markus and Mao make a distinction between stakeholders and participants, and elaborate on the role of a 'change agent'. By our case study we demonstrated that change agents play a key role as they have to decide who are participants, how they will participate and what participation techniques are most useful for IS/IT success .

For practitioners, the results offer several relevant findings. A first suggestion is to realise that next to management support it is important to take the stakeholder context into account. Second, practitioners should invest in alignment and vision sharing between different stakeholders, to achieve successful metastructuration actions. Third, management should play an active role to realise a cooperative climate. We suggest that practical and relational behaviours by management achieve more impact than documents such as newsletters and memo's .

There are, of course, also limitations to this study. First, we considered three case studies of the implementation of IS/IT projects. Although this approach has provided useful data about these projects, it is important to realise that the information obtained is bound to the context of the case studies, and therefore not automatically applicable in a broader context. Therefore, more case studies are needed to validate the findings. Second, while we have tried to rule out confounding factors, we are aware that other factors can have influenced the results.

\section{CONCLUSIONS}

In healthcare, the acceptance of IS/IT is highly important because of its societalsensitivity and high stakeholder density. Therefore, the process of IS/IT acceptation managed is key. This paper has identified a number of key metastructuration actions related to awareness creation, training, and user participation. These can have significant effects on IS/IT success when influenced by the identified stakeholder issues alignment and vision sharing. Although these findings need to be confirmed and extended by further research, the relevant message is that the process of acceptation can be positively managed by identifying, and taking into account the interrelations between stakeholders, their alignment, and their vision sharing . 
Waal, B.M.E. de, Batenburg, R., Fruytier, B. Metastructuration actions of management: critical for stakeholder intervention in IS/IT implementations. International Journal of Healthcare

Technology and Management: 2012, 13(4), 242-261

\section{REFERENCES}

Akkermans, H. and Van Helden, K. (2002) 'Vicious and virtuous in ERP implementation: a case study of interrelations between critical success factors', European Journal of Information

Systems, Vol. 11, No. 1, pp.35-46.

Allsop, J. and Taket, A. (2003) 'Evaluating user involvement in primary healthcare', International

Journal of Healthcare Technology and Management, Vol. 5, No. 1/2, pp.34-44 .

Axelsson, K., Melin, U. and Söderström, F. (2011) 'Analysing best practices and critical success factors in a health information system case - are there any shortcuts to successful IT implementation?', in Tuunainen, V., Nandhakumar, J., Rossi, M. and Soliman, W. (Eds.): In 19th European Conference on Information Systems, Helsinki, Finland, pp.2157-2168 .

Barki, H. and Hartwick, J. (1989) 'Rethinking the concept of user involvement', MIS Quarterly, Vol. 13, No. 1, pp.53-63.

Barki, H. and Hartwick, J. (1994) 'Measuring user participation, user involvement, and user attitude', MIS Quarterly, Vol. 18, No. 1, pp.59-82 .

Boeije, H. (2002) 'A purposeful approach to the constant comparative method in the analysis of qualitative interviews', Quality \& Quantity, Vol. 36, No. 4, pp.391-409 .

Boonstra, A., Boddy, D. and Bell, S. (2008) 'Stakeholder management in IOS projects: analyses of an attempt to implement an electronic patient file', European Journal of Information Systems, Vol. 17, No. 2, pp.100-111.

Chan, C.M.L. and Pan, S.L. (2008) 'User engagement in e-government systems implementation: a comparative case study of two Singaporean e-government initiatives', Journal of Strategic

Information Systems, Vol. 17, No. 2, pp.124-139.

Chiasson, M., Reddy, M., Kaplan, B., Davidson, E. (2007) ‘Expanding multi-disciplinary approaches to healthcare information technologies: what does information systems offer medical informatics?', International Journal of Medical Informatics, Vol. 76, No. 1, pp.S89S97.

DeLone, W.H. and McLean, E.R. (1992) 'Information systems success: the quest for the dependent variable', Information Systems Research, Vol. 3, No. 1, pp.60-95 .

DeLone, W.H. and McLean, E.R. (2003) 'The DeLone and McLean model of information systems success: a ten-year update', Journal of Management Information Systems, Vol. 19, No. 4, pp.9-30.

Donaldson, T. and Preston, L. (1995) 'The stakeholder theory of the modern corporation: concepts, evidence and implications', Academy of Management Review, Vol. 20, No. 1, pp.65-91 .

Dong, L., Neufeld, D. and Higgens, C. (2009) 'Top management support of enterprise systems implementation', Journal of Information Technology, Vol. 24, No. 1, pp.55-80 .

Fehse, K. and Krabbendam, K. (2004). 'How organisational politics explain IS implementation outcomes in hospitals', International Journal of Electronic Healthcare, Vol. 1, No. 2, pp.139-148

Griffith, T.L. and Sobol, M.G. (2000) 'Negotiating medical technology implementation: overcoming power and stakeholder diversity', International Journal of Healthcare Technology

and Management, Vol. 2, Nos. 1/2/3/4, pp.375-392 .

Hartwick, J. and Barki, H. (1994) 'Explaining the role of user participation in information system use', Management Science, Vol. 40, No. 4, pp.440-465 .

$\mathrm{He}$, J. and King, W.R. (2008) 'The role of user participation in information systems development: implications from a meta-analysis', Journal of Management Information Systems, Vol. 25, No. 1, pp.301-331.

Hebert, M.A. (2000) 'Impact of patient care information systems on healthcare professionals and patient care in two community hospitals', International Journal of Healthcare Technology and

Management, Vol. 2, Nos. 1/2/3/4, pp.393-401 .

Jensen, T.B., Kjaergaard, A. and Svejvig, P. (2009) 'Using institutional theory with sensemaking theory: a case study of information system implementation in healthcare', Journal of 
Waal, B.M.E. de, Batenburg, R., Fruytier, B. Metastructuration actions of management: critical for stakeholder intervention in IS/IT implementations. International Journal of Healthcare Technology and Management: 2012, 13(4), 242-261

Information Technology, Vol. 24, No. 4, pp.343-353 .

Jeyaraj, A. and Sabherwal, R. (2008) 'Adoption of information systems innovations by individuals: a study of processes involving contextual, adopter, and influencer actions', Information and

Organization, Vol. 18, No. 3, pp.205-234 .

Kappelman, L.A. and McLean, E.R. (1991) 'The respective roles of user participation and user involvement in information system implementation success'. Proceedings of the Twelfth

International Conference on Information Systems, New York, USA, pp.339-349

Kirsch, L. (2004) 'Deploying common systems globally: the dynamics of control', Information System Research, Vol. 15, No. 4, pp.374-395 .

Klein, $\mathrm{H}$. and Myers, M. (1999) 'A set of principles for conducting and evaluating interpretive field studies in information systems', MIS Quarterly, Vol. 23, No. 1, pp.67-93

Ko, D-G., Kirsch, L.J. and King, W.R. (2005) 'Antecedents of knowledge transfer from consultants to clients in enterprise system implementation', MIS Quarterly, Vol. 29, No. 1, pp.59-85

Lewis, W., Agarwal, R. and Sambamurthy, V. (2003) 'Sources of influence on beliefs about information technology use: an empirical study of knowledge workers', MIS Quarterly, Vol. 27, No. 4, pp.657-678

Lin, A. and Silva, L. (2005) 'The social and political construction of technological frames', European Journal of Information Systems, Vol. 14, No. 1, pp.49-59 .

Lynch, T. and Gregor, S. (2004) 'User participation in decision support systems development: influencing system outcomes', European Journal of Information Systems, Vol. 13, No. 4, pp.286-301.

Madill, A., Jordan, A. and Shirley, C. (2000) 'Objectivity and reliability in qualitative analysis: realist, contextualist and radical constructionist epistemologies', British Journal of

Psychology, Vol. 91, No. 1, pp.1-20.

Mantzana, V., Themistocleous, M., Irani, Z. and Morabito, V. (2007) 'Identifying healthcare actors involved in the adoption of information systems', European Journal of Information Systems, Vol. 16, No. 1, pp.91-102.

Markus, M.L. and Keil, M. (1994) 'If we build it, they will come: designing information systems that people want to use', Sloan Management Review, Vol. 35, No. 4, pp.11-25 .

Markus, M.L. and Mao, J-Y. (2004) 'Participation in development and implementation updating an old, tired concept for today's IS contexts', Journal of the Association for Information

Systems, Vol. 5, Nos. 11-12, pp.514-544 .

Mignaret, M. and Rivard, S. (2009) 'Positioning the institutional perspective in information systems research', Journal of Information Technology, Vol. 24, No. 4, pp.369-391 .

Miles, M.B. and Huberman, A. (1994) Qualitative Data Analysis: An Expanded Sourcebook, Sage Publications, Thousand Oaks .

Mitroff, I. (1983) Stakeholders of the Organizational Mind, Jossey-Bass, San Francisco, CA . Nasirin, S., Winter, N. and Coppock, P. (2005) 'Factors influencing user involvement DSS project implementation: some lessons from the United Kingdom health sector', Proceedings of the

Thirteenth European Conference on Information Systems, Regensburg, Germany, pp.104114 .

Neuman, W.L. (2002) Social Research Methods: Qualitative and Quantitative Approaches, Pearson Education, Boston .

Nordheim, S. and Nielsen, P.A. (2008) 'Enterprise system implementations: organizational influence processes for corporate user representatives', Proceedings of the 16th European Conference on Information Systems, Galway, Ireland, pp.362-373 .

Orlikowski, W.J. (1992) 'The duality of technology: rethinking the concept of technology in organizations', Organization Science, Vol. 34, No. 3, pp.398-427 .

Orlikowski, W.J. (2000) 'Using technology and constituting structures: a practice lens for studying technology in organizations', Organization Science, Vol. 11, No. 4, pp.404-428 .

Orlikowski, W.J., Yates, J., Okamura, K. and Fujimoto, M. (1995) 'Shaping electronic communication: the metastructuring of technology in the context of use', Organization Science, Vol. 6, No. 4, pp.423-444 . 
Waal, B.M.E. de, Batenburg, R., Fruytier, B. Metastructuration actions of management: critical for stakeholder intervention in IS/IT implementations. International Journal of Healthcare Technology and Management: 2012, 13(4), 242-261

Patton, M.Q. (2002) Qualitative Research and Evaluation Methods, Sage Publications, Thousand Oaks .

Purvis, R.L., Sambamurthy, V. and Zmud, R.W. (2001) 'The assimilation of knowledge platforms in organizations: an empirical investigation', Organization Science, Vol. 12, No. 2, pp.117-135 .

Rowley, T.J. (1997) 'Moving beyond dyadic ties: a network theory of stakeholder influences', Academy of Management Review, Vol. 22, No. 4, pp.887-910.

Runeson, P. and Höst, M. (2009) 'Guidelines for conducting and reporting case study research in software engineering', Empirical Software Engineering, Vol. 14, No. 2, pp.131164 .

Seddon, P.B., Staples, S., Patnayakuni, R. and Bowtell, M. (1999) 'Dimensions of information systems success', CAIS, Vol. 2, No. 20, pp.1-32 .

Sharma, R. and Yetton, P. (2003) 'The contingent effects of management support and task interdependence on successful information systems implementation', MIS Quarterly, Vol. 27, No. 4, pp.533-556.

Somers, T.M. and Nelson, K.G. (2001) 'The impact of critical success factors across the stages of enterprise resource planning implementations', Proceedings of the 34th Annual Hawaii

International Conference on System Sciences (HICSS-34), Vol. 8, Maui, Hawaii .

Strong, D.M., Volkoff, O., Johnson, S.A., Bar-On, I. and Pelletier, L. (2009) 'Electronic health records and the changing roles of health care professionals: a social informatics perspective', Proceedings of the Fifteenth Americas Conference on Information Systems, San Francisco, California, 6-9 August 2009.

Venkatesh, V., Morris, M.G. and Davis, G.B. (2003) 'User acceptance of information technology: toward a unified view', MIS Quarterly, Vol. 27, No. 3, pp.425-479 .

Walley, P. and Davies, C. (2002) 'Implementing IT in NHS hospitals - internal barriers to technological advancement', International Journal of Healthcare Technology and Management, Vol. 4, Nos. 3/4, pp.259-272 .

Wolfe, R.A. and Putler, D.S. (2002) 'How tight are the ties that bind stakeholder groups?', Organization Science, Vol. 13, No. 1, pp.64-80 .

Yin, R.K. (2009) Case Study Research, Sage Publications, Thousand Oaks .

\section{[APPENDIX]}


Waal, B.M.E. de, Batenburg, R., Fruytier, B. Metastructuration actions of management: critical for stakeholder intervention in IS/IT implementations. International Journal of Healthcare Technology and Management: 2012, 13(4), 242-261

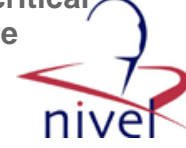

TABLES, FIGURES AND APPENDIX

Figure 1 Conceptual model of management support and IS/IT success (see online version for colours)
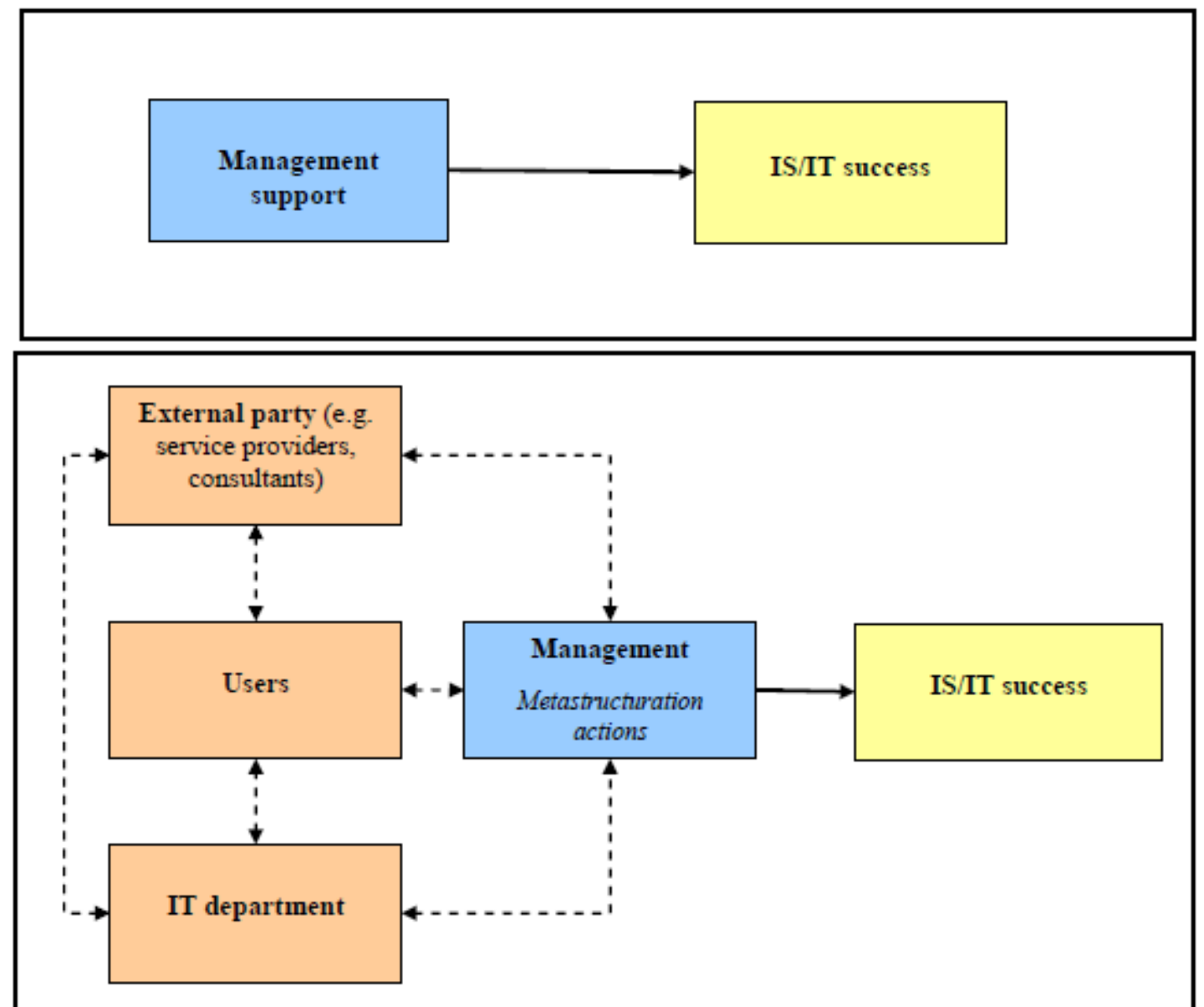

Figure 3 Time frame of the SMH project

\begin{tabular}{l|llll}
$\begin{array}{l}\text { Start information } \\
\text { requirement } \\
\text { study by IT } \\
\text { department }\end{array}$ & $\begin{array}{l}\text { European tender } \\
\text { announced }\end{array}$ & $\begin{array}{l}\text { Development of } \\
\text { client tracking } \\
\text { system; new } \\
\text { requirement } \\
\text { analysis }\end{array}$ & $\begin{array}{l}\text { Implementation } \\
\text { of client tracking } \\
\text { system }\end{array}$ & $\begin{array}{l}\text { Role of service } \\
\text { provider became } \\
\text { system } \\
\text { administrator }\end{array}$ \\
\hline 1999 & 2001 & 2002 & 2003 & 2004
\end{tabular}

Figure 4 Time frame of the YHC project

\begin{tabular}{|c|c|c|c|c|}
\hline $\begin{array}{l}\text { Start to digitise } \\
\text { client } \\
\text { administration in } \\
\text { cooperation with } \\
\text { another public } \\
\text { healthcare } \\
\text { organisation }\end{array}$ & $\begin{array}{l}\text { European tender } \\
\text { announced; } \\
\text { development of IS } \\
\text { in cooperation } \\
\text { with various } \\
\text { working groups }\end{array}$ & $\begin{array}{l}\text { Incremental } \\
\text { implementation } \\
\text { of IS }\end{array}$ & $\begin{array}{l}\text { Original service } \\
\text { provider stopped; } \\
\text { new European } \\
\text { tender announced; } \\
\text { combination of } \\
\text { service providers }\end{array}$ & $\begin{array}{l}\text { More public } \\
\text { health care } \\
\text { organisations use } \\
\text { the system }\end{array}$ \\
\hline
\end{tabular}

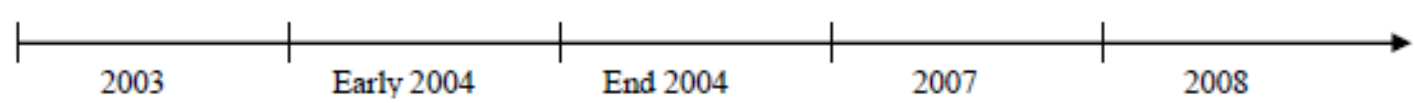


Waal, B.M.E. de, Batenburg, R., Fruytier, B. Metastructuration actions of management: critical for stakeholder intervention in IS/IT implementations. International Journal of Healthcare Technology and Management: 2012, 13(4), 242-261

Figure 5 Time frame of the ID project

\begin{tabular}{|c|c|c|c|c|}
\hline $\begin{array}{l}\text { Need for a new } \\
\text { IS; } \\
\text { information } \\
\text { requirement } \\
\text { analysis by } \\
\text { external }\end{array}$ & $\begin{array}{l}\text { European tender } \\
\text { announcement } \\
\text { for SOA } \\
\text { policlinic and } \\
\text { global infectious } \\
\text { diseases }\end{array}$ & $\begin{array}{l}\text { Development of } \\
\text { IS; } \\
\text { European tender } \\
\text { announcement } \\
\text { for regional } \\
\text { laboratory }\end{array}$ & $\begin{array}{l}\text { Implementation } \\
\text { of IS; } \\
\text { train-the-trainer } \\
\text { programme }\end{array}$ & $\begin{array}{l}\text { New demands } \\
\text { and wishes } \\
\text { installed by } \\
\text { service provider }\end{array}$ \\
\hline
\end{tabular}

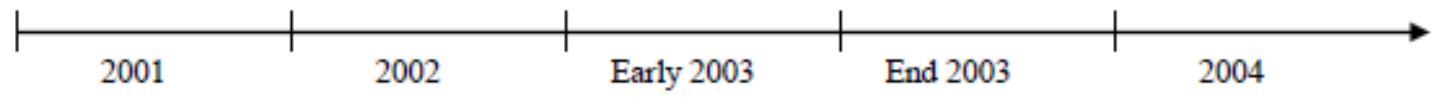

Table 1 Number of interviews by cluster and stakeholder

\begin{tabular}{lccc}
\hline Stakeholder & SMH & YHC & ID \\
\hline Management & 4 & 2 & 3 \\
User & 2 & 3 & 3 \\
IT department & 2 & 2 & 2 \\
External party & 1 & 2 & - \\
\hline
\end{tabular}

Table 2 Summary of data analysis methods

\begin{tabular}{|c|c|c|c|}
\hline Step & Activity & Nature & Method \\
\hline 1 & Code stakeholder A of case 1 & $\begin{array}{l}\text { Within-stakeholder } \\
\text { analysis }\end{array}$ & Open and axial coding \\
\hline 2 & $\begin{array}{c}\text { Code stakeholders B, C and D of } \\
\text { case } 1\end{array}$ & $\begin{array}{l}\text { Within-stakeholder } \\
\text { analysis }\end{array}$ & Open and axial coding \\
\hline 3 & $\begin{array}{l}\text { Conduct between-stakeholder } \\
\text { comparison of case } 1\end{array}$ & Within-case analysis & Selective coding \\
\hline 4 & $\begin{array}{c}\text { Repeat step } 1,2 \text { and } 3 \text { for case } 2 \\
\text { and } 3\end{array}$ & See step 1,2 and 3 & See step 1,2 and 3 \\
\hline 5 & $\begin{array}{l}\text { Conduct between-case } \\
\text { comparison }\end{array}$ & Between-case analysis & Pattern analysis \\
\hline 6 & $\begin{array}{l}\text { Compare findings with previous } \\
\text { studies }\end{array}$ & $\begin{array}{c}\text { Between-case inductive } \\
\text { analysis }\end{array}$ & Pattern analysis \\
\hline
\end{tabular}




\begin{tabular}{|c|c|c|c|c|c|c|c|}
\hline Categories & Concepts & & Project SMH & & Project $Y H C$ & & Project ID \\
\hline \multirow[t]{3}{*}{$\begin{array}{l}\text { Implementation } \\
\text { context }\end{array}$} & $\begin{array}{l}\text { Characteristics of the } \\
\text { system }\end{array}$ & & - Client tracking system & & $\begin{array}{l}\text { - Business application to } \\
\text { digitise client administration }\end{array}$ & & $\begin{array}{l}\text { - Business application to } \\
\text { replace legacy system }\end{array}$ \\
\hline & Project management & & - One project champion & & - Two project co-cham pions & & - One project champion \\
\hline & structure & & $\begin{array}{l}\text { - Steering committee, project } \\
\text { manager and project leader, } \\
\text { working group, super user } \\
\text { group }\end{array}$ & & $\begin{array}{l}\text { - Steering committee, project } \\
\text { manager, working groups }\end{array}$ & & $\begin{array}{l}\text { - Steering committee, project } \\
\text { manager, vendor working } \\
\text { group }\end{array}$ \\
\hline \multirow[t]{6}{*}{$\begin{array}{l}\text { Management } \\
\text { support }\end{array}$} & Awareness creation & M & $\begin{array}{l}\text { Team leaders set no pressure to } \\
\text { use the system and had no } \\
\text { concern on work instructions }\end{array}$ & M & $\begin{array}{l}\text { Insufficient guidance to the } \\
\text { process of implementing and } \\
\text { communicating }\end{array}$ & $\mathrm{U}$ & $\begin{array}{l}\text { Information bulletin to inform } \\
\text { employees about the } \\
\text { development of the system }\end{array}$ \\
\hline & & $\mathrm{U}$ & $\begin{array}{l}\text { No clear direction and } \\
\text { systematic control on what was } \\
\text { decided }\end{array}$ & $\mathrm{U}$ & $\begin{array}{l}\text { During implementation, support } \\
\text { was available and there was no } \\
\text { time pressure }\end{array}$ & $\mathrm{U}$ & $\begin{array}{l}\text { Early training to prevent } \\
\text { resistance }\end{array}$ \\
\hline & & E & $\begin{array}{l}\text { Management gives insufficient } \\
\text { attention to the usage of the } \\
\text { system }\end{array}$ & $\mathrm{E}$ & $\begin{array}{l}\text { Commitment to the project was } \\
\text { different for each regional } \\
\text { manager }\end{array}$ & & \\
\hline & Training & M & $\begin{array}{l}\text { Employee training was not } \\
\text { optimal }\end{array}$ & M & $\begin{array}{l}\text { Additional training to learn tricks } \\
\text { to facilitate system use }\end{array}$ & M & $\begin{array}{l}\text { Much training was needed to } \\
\text { learn the system }\end{array}$ \\
\hline & & I & There was a need for training & $\mathrm{U}$ & $\begin{array}{l}\text { Training was offered to all users, } \\
\text { but not always used }\end{array}$ & $\mathrm{U}$ & $\begin{array}{l}\text { Discussion about the amount of } \\
\text { training }\end{array}$ \\
\hline & & & & $\mathrm{E}$ & $\begin{array}{l}\text { By time pressure, no time was } \\
\text { spent on good practice and testing } \\
\text { of the system }\end{array}$ & & \\
\hline
\end{tabular}




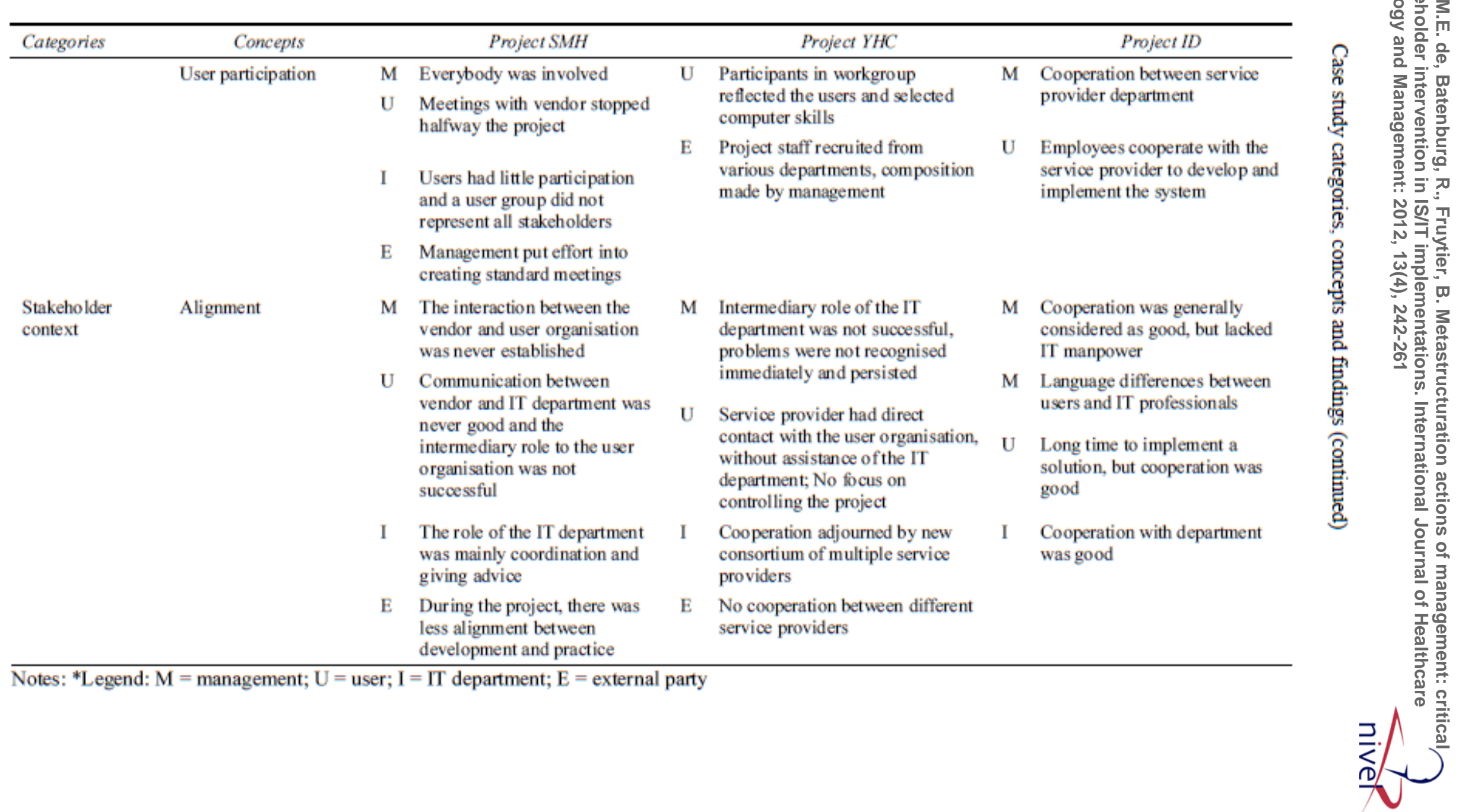




\begin{tabular}{|c|c|c|c|c|c|c|c|}
\hline Categories & Concepts & & Project SMH & & Project YHC & & Project ID \\
\hline & Vision sharing & M & $\begin{array}{l}\text { No agreement about the } \\
\text { purpose of the system }\end{array}$ & M & $\begin{array}{l}\text { Not clear that the system was } \\
\text { built to support business }\end{array}$ & M & $\begin{array}{l}\text { System to register activities to } \\
\text { monitor and follow patients }\end{array}$ \\
\hline & & $\mathrm{U}$ & $\begin{array}{l}\text { The departments had very } \\
\text { different information needs }\end{array}$ & & $\begin{array}{l}\text { processes or management } \\
\text { information }\end{array}$ & $\mathrm{U}$ & $\begin{array}{l}\text { System more than registration, } \\
\text { also decision support which }\end{array}$ \\
\hline & & & & $\mathrm{U}$ & Expectations were high, digitise & & research must be done \\
\hline & & I & $\begin{array}{l}\text { There was a lack of a clear } \\
\text { vision }\end{array}$ & & $\begin{array}{l}\text { paper documents and planning, } \\
\text { management information and } \\
\text { research on epidemiological data }\end{array}$ & I & Disagreement to develop one \\
\hline & & $\mathrm{E}$ & There were different priorities & I & $\begin{array}{l}\text { Building a digital system because } \\
\text { of operating considerations, } \\
\text { namely a more efficient way of } \\
\text { working }\end{array}$ & & or more systems \\
\hline & & & & $\mathrm{E}$ & $\begin{array}{l}\text { No agreement about the goal of } \\
\text { the system }\end{array}$ & & \\
\hline \multirow[t]{8}{*}{ IS/IT sucoess } & System quality & M & $\begin{array}{l}\text { Users do not use the system in } \\
\text { the right way }\end{array}$ & M & $\begin{array}{l}\text { System operates reasonably well; } \\
\text { only performance problems }\end{array}$ & M & \multirow{2}{*}{$\begin{array}{l}\text { Requirements were partly } \\
\text { satisfied, management } \\
\text { information and scientific } \\
\text { analysis are hard to get }\end{array}$} \\
\hline & & \multirow[t]{3}{*}{$\mathrm{U}$} & \multirow{3}{*}{$\begin{array}{l}\text { The quality of the system did } \\
\text { not fulfil expectations, and not } \\
\text { satisfied about usability }\end{array}$} & $\mathrm{U}$ & $\begin{array}{l}\text { More transparency and flexibility } \\
\text { and better system performance }\end{array}$ & & \\
\hline & & & & I & $\begin{array}{l}\text { Workflow was not in line with } \\
\text { actual work processes, } \\
\text { performance problems were } \\
\text { solved }\end{array}$ & $\mathrm{U}$ & $\begin{array}{l}\text { Most requirements are real ised, } \\
\text { usability could be better }\end{array}$ \\
\hline & & & & $\mathrm{E}$ & $\begin{array}{l}\text { Work process did not fit with the } \\
\text { workflow of the system }\end{array}$ & & \\
\hline & \multirow[t]{4}{*}{ Acceptance } & \multirow[t]{2}{*}{$\mathrm{U}$} & \multirow[t]{2}{*}{$\begin{array}{l}\text { Resistance as a result of } \\
\text { prematurely ending projects } \\
\text { and insufficient releases }\end{array}$} & M & $\begin{array}{l}\text { System had a negative impact on } \\
\text { daily practice, acoeptance } \\
\text { decreased }\end{array}$ & $\mathrm{U}$ & $\begin{array}{l}\text { Everyone worked with the } \\
\text { system, although not 'in depth" }\end{array}$ \\
\hline & & & & $\mathrm{U}$ & $\begin{array}{l}\text { Feeling of being pushed by } \\
\text { system }\end{array}$ & $\mathrm{U}$ & $\begin{array}{l}\text { Resistance was increasingly } \\
\text { removed }\end{array}$ \\
\hline & & I & $\begin{array}{l}\text { Limited use and understanding } \\
\text { of the system by users }\end{array}$ & \multirow[t]{2}{*}{ I } & \multirow{2}{*}{$\begin{array}{l}\text { Many employees without } \\
\text { computer experience, there fore } \\
\text { significant level of resistance }\end{array}$} & & \\
\hline & & $\mathrm{E}$ & $\begin{array}{l}\text { At the beginning limited and } \\
\text { avoided the use of the system }\end{array}$ & & & & \\
\hline
\end{tabular}

Notes: "Legend: $\mathrm{M}=$ management; $\mathrm{U}=$ user; $\mathrm{I}=\mathrm{IT}$ department; $\mathrm{E}=$ external party 
Waal, B.M.E. de, Batenburg, R., Fruytier, B. Metastructuration actions of management: critical for stakeholder intervention in IS/IT implementations. International Journal of Healthcare Technology and Management: 2012, 13(4), 242-261

Table 4 Summary of management support, stakeholder context and IS/IT success

\begin{tabular}{|c|c|c|c|c|}
\hline Categories & Concepts & Project SMH & Project YHC & Project ID \\
\hline $\begin{array}{l}\text { Management } \\
\text { support }\end{array}$ & $\begin{array}{l}\text { - Awareness } \\
\text { creation } \\
\text { - Training } \\
\text { - User } \\
\text { participation }\end{array}$ & $\begin{array}{l}\text { - Low } \\
\text { - Moderate } \\
\text { - Moderate }\end{array}$ & $\begin{array}{l}\text { - Moderate } \\
\text { - Moderate } \\
\text { - Moderate }\end{array}$ & $\begin{array}{ll}\text { - } & \text { High } \\
\text { - } & \text { Moderate } \\
\text { - } & \text { High }\end{array}$ \\
\hline $\begin{array}{l}\text { Stakeholder } \\
\text { context }\end{array}$ & $\begin{array}{l}\text { - Alignment } \\
\text { - Vision sharing }\end{array}$ & $\begin{array}{l}\text { - Low } \\
\text { - Low }\end{array}$ & $\begin{array}{l}\text { - Low } \\
\text { - Low }\end{array}$ & $\begin{array}{l}\text { - } \text { High } \\
\text { - } \text { Moderate }\end{array}$ \\
\hline IS/IT success & $\begin{array}{l}\text { - System quality } \\
\text { - Acceptance }\end{array}$ & $\begin{array}{l}\text { - Low } \\
\text { - Low }\end{array}$ & $\begin{array}{l}\text { - Moderate } \\
\text { - Low }\end{array}$ & $\begin{array}{l}\text { - } \text { Moderate } \\
\text { - High }\end{array}$ \\
\hline
\end{tabular}

Appendix

\section{Interview guide}

- How was the project started?

- How was the project structured?

- What was done to gain support for the project?

- How were users involved in the project (type of participation, training, prototyping)?

- What was the task of (top) management?

- What was the task of the IT department?

- What was the task of the user organisation?

- What are the experiences with the usefulness of the system?

- What are the experiences with the usability of the system?

- What can you tell me about the use of the system? 